\title{
INFLUENCE OF POTATO CULTIVAR AND STAGE OF MATURITY ON OIL CONTENT OF FRENCH FRIES (CHIPS) MADE FROM EIGHT KENYAN POTATO CULTIVARS
}

\author{
Abong GO, ${ }^{1 *}$, Okoth $\mathrm{MW}^{1}$, Karuri EG ${ }^{1}$, Kabira $\mathrm{JN}^{2}$ and FM Mathooko ${ }^{3}$
}

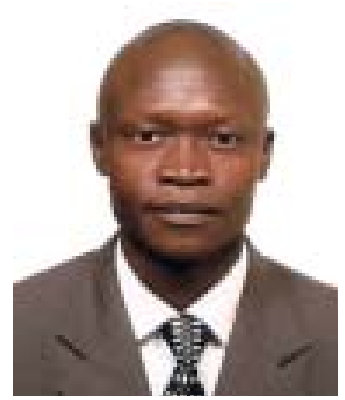

Abong George

*Corresponding author Email: georkoyo@yahoo.com or ooko.george@uonbi.ac.ke

${ }^{1}$ Department of Food Science, Nutrition and Technology, University of Nairobi, P.O. Box 29053-00625, Nairobi (Kangemi), Kenya.

${ }^{2}$ National Potato Research Centre (KARI), Tigoni, P.O. Box 338, Limuru, Kenya.

${ }^{3}$ South Eastern University College, P.O Box 170- 90200, Kitui, Kenya. 


\section{ABSTRACT}

French fries (chips) are increasingly becoming indispensable in menus of many restaurants and hotels in major Kenyan towns due to their relatively lower consumer prices compared to other foods. When foods are deep-oil-fried, the amount of oil absorbed by the food is important since nutritionally, the amount of oil absorbed has a marked bearing on the number of calories supplied by the food. Fried foods such as chips may contain a considerable amount of oil to such extent that their consumption is of concern to nutritionists who advocate for a decrease or an increase of fat content in the diet depending on the part of the world where they are based. Chips with lower oil content and equivalent sensory attributes are expected to be highly accepted by consumers. The influence of potato cultivar and stage of maturity on uptake of oil into chips was investigated using eight Kenyan cultivars including five varieties (Tigoni, Desiree, Dutch Robyjn, Kenya Karibu, and Kenya Sifa) and three promising potato clones coded as 393385.47, 391696.96 and 393385.39. The eight cultivars were grown under cultural standard conditions at the National Potato Research Centre, Tigoni. The crop was dehaulmed two weeks before harvesting and allowed to cure at ambient air conditions $\left(15-19{ }^{\circ} \mathrm{C} / 86-92 \% \mathrm{RH}\right)$ for three weeks. The potatoes were harvested at 90 or 120 days after planting. The variety of potato used had a significant effect $(\mathrm{P} \leq 0.05)$ on oil uptake, with Dutch Robyjn having the lowest oil content. The cellular structures may have affected the oil uptake into the chips by influencing solid content, moisture loss during frying or damage done to original anatomy during processing. Harvesting before maturity significantly $(\mathrm{P} \leq 0.05)$ increased oil content of chips when compared to those prepared from mature tubers. There is need for processors to wisely choose the potato cultivar in order to produce French fries with low oil content.

Key words: Cultivars, fries, oil, sensory attributes 


\section{INTRODUCTION}

Potatoes (Solanum tuberosum) are plants that belong to the Solanaceae family commonly grown for starchy tubers. The potatoes were introduced by the British farmers and colonial officials into Kenya during the 1880s. Once introduced into the country, new varieties were developed to suit the local conditions [1].

Currently, many varieties that differ in texture, flavour, shape and colour are grown in Kenya as a food and cash crop. According to the National Policy on Potato Industry [2], the potato in Kenya is an important food and cash crop that plays a major role in food security and is only second to maize in terms of utilization. The production of potatoes is increasing due to economic decline of competing cash crops such as maize, pyrethrum and barley, and increasing demand from consumers and processors. By 2003, the number of potato growers in Kenya was estimated to be 500,000 in an area of 108,000 hectares with total production of 1 million tonnes in two growing seasons [2].

Potatoes are widely consumed in Kenya, especially in the major growing areas in Central (Murang'a, Nyeri, Kiambu, Kirinyaga, Maragua, Thika, and Nyandarua), Rift valley (Molo, Nakuru, Bomet, Uasin Gishu, Koibatek and Mau Narok), Eastern (Meru), with small quantities in the high altitudes of Western and Coast provinces. The most important products in the Kenyan potato processing industry are potato chips (French fries), followed by crisps and frozen French fries whose demands have rapidly increased as witnessed by rapid growth of fast food restaurants and snack bars in the urban areas [3]. French fries are increasingly becoming indispensable in menus of many restaurants and hotels in major Kenyan towns due to their relatively lower consumer prices compared to other foods.

When foods are deep-oil-fried, the amount of oil absorbed by the food is important for several reasons. Nutritionally, the amount of oil absorbed has a marked bearing on the number of calories supplied by the food. Fried foods may contain amounts of oil that in some cases is more than $45 \%$ of the weight of the total product [4]. French fries, for example, contain about $15 \%$ oil [5]. As such, their consumption is of concern to nutritionists who advocate a decrease or an increase of fat content in the diet depending on the part of the world where they are based. Hagenimana et al. [6] found oil to be among the most expensive ingredients in processing home based foods. French fries with lower oil content and equivalent sensory attributes are expected to be accepted by the increasing number of cautious consumers.

Many factors have been reported to affect the oil content of French fries including oil quality, frying temperature and duration, product shape and composition (moisture content, solids, fat, gel-strength, and proteins), pre-frying techniques (blanching, drying and frying) and coating [7, 8]. Gamble et al. [4] found the loss of moisture and the oil up take during frying to be interrelated and recommended a reduction of the initial moisture content by drying to reduce the fat uptake into potatoes.

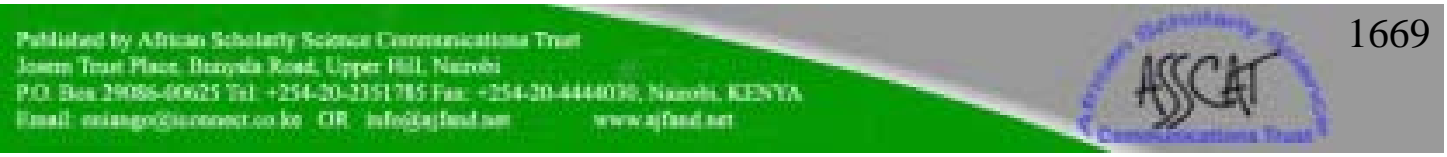


Development of lower calorie, lower oil French fries for the quick service restaurants has to some extent been achieved by either reformulating the product, changing the finish frying step, or a combination of both [9]. Selection of appropriate variety, however, is also very important when considering the oil uptake into chips [10]. The present study investigated the oil uptake of French fries as influenced by variety and stage of maturity in 8 Kenyan potato cultivars.

\section{MATERIALS AND METHODS}

\section{Potato growing}

Eight Kenyan cultivars (plants developed from natural species and maintained under cultivation) including five potato varieties (plant categories consisting of members of a species that differ from others of the same species in minor but well known heritable characteristics); Tigoni, Desiree, Dutch Robyjn, Kenya Karibu and Kenya Sifa and three potato clones (plant species resulting from combination of genes from two or more varieties and bearing identical characteristics to the common parents) coded as 393385.47, 391696.96 and 393385.39 from the International Potato Center (CIP) were grown at the National Potato Research Center, Tigoni in the year 2007 under standard cultural conditions [11]. The crop was dehaulmed (leaves and stems were removed) two weeks before harvesting. After harvesting, the tubers were allowed to cure at ambient air conditions (15-19 $\left.{ }^{\circ} \mathrm{C} / 86-92 \% \mathrm{RH}\right)$ for three weeks. The potatoes were harvested at 90 or 120 days after planting. The processing and evaluation were carried out in the food science laboratories at the Kenya Agricultural Research Station (KARI) in Tigoni (processing and sensory evaluation), the Jomo Kenyatta University of Agriculture and Technology (chemical and colour analysis) and at the College of Agriculture and Veterinary Sciences of the University of Nairobi (validation of chemical analysis results).

\section{Preparation of potatoes for processing}

After harvesting, $18 \mathrm{~kg}$ of ware (table) potatoes (50 $\mathrm{mm}$ and above in diameter) were selected and packed in plastic net bags. They were then left to cure at ambient air conditions (15-19 $\left.{ }^{\circ} \mathrm{C} / 86-92 \% \mathrm{rh}\right)$ for three weeks in a naturally ventilated dark store before processing and sensory evaluation were done.

\section{Analytical methods}

\section{Determination of moisture content}

The moisture content of fresh tubers and processed products was obtained by standard analytical method [12]. Triplicate samples $(5 \mathrm{~g})$ were weighed in aluminum dishes and oven dried at $105{ }^{\circ} \mathrm{C}$ to constant weight. The dried samples were cooled in a dessicator to room temperature and weighed. Loss of weight due to drying was converted to percent moisture content as follows:

Moisture $\%=$ (weight of moisture evaporated/weight of sample) $\mathrm{x} 100$.

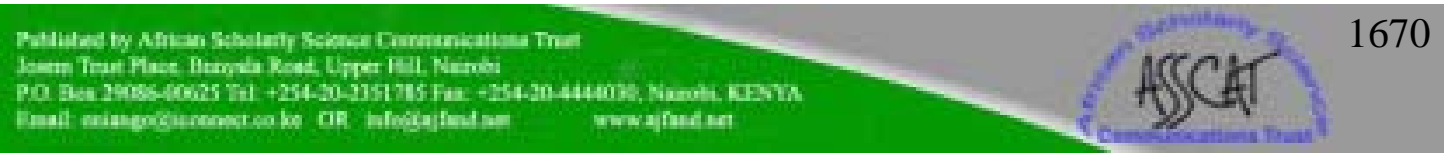




\section{Oil content determination}

After drying, French fries were finely ground in a blender and duplicate $5 \mathrm{~g}$ samples were put into thimbles, 16-hr Soxhlet extraction was conducted using analytical grade petroleum ether (boiling point $40-60{ }^{\circ} \mathrm{C}$ ) as described by Lulai and Orr [13].

\section{French fries preparation}

Potato tubers were hand-peeled, and cut lengthwise using a hand-operated chip cutter producing 12x12 mm strips in cross-section. Short or broken pieces less than $30 \mathrm{~mm}$ were removed. These strips were washed in cold tap water to remove surface starch. A clean cloth towel was used to surface-dry the washed strips before frying in an institution size, batch type, deep fat fryer (E-6 ARO S.A., La Neuveville, Switzerland) containing about 7 litres of "Elianto" corn oil maintained at a fixed temperature of $170{ }^{\circ} \mathrm{C}$. Frying was accomplished in two stages: par-frying ( $2 \mathrm{~min}$ ), and finish frying $(5 \mathrm{~min})$. The fat fried strips were drained of oil $(1 \mathrm{~min})$, placed on plates and left to cool at room temperature before being packaged into polyvinyl chloride bags (PVC, gauge 125), sealed, and taken to the laboratory for analysis.

\section{Sensory evaluation and colour of French fries}

To evaluate effects of fat absorption and acceptability of potato French fries to potential consumers, sensory analysis was performed by a panel of 10 members from the Kenya National Potato Research Station, Tigoni. Coded samples were presented to the panellists and scored for colour, texture, flavour, oiliness and overall acceptability on a 9-point hedonic scale as shown in Table 1 [14]. A score of 5 was the lower limit of acceptability. Analysis of variance was done to compare the difference in chips quality as affected by oil absorption.

\section{Data analysis}

Analysis of variance (ANOVA) and least significant difference test for the variables was conducted using the Statistical Analysis System (SAS version 9). Correlation analysis was performed to determine linear relationship between tuber dry matter content and oil content, and also between oil content determined by Soxhlet extraction and panelists scores on oiliness by Microsoft Excel Spreadsheet and Statistical Analysis System.

\section{RESULTS}

\section{Correlation of dry matter and oil content}

Dry matter content ranged from 19.50 to $24.07 \%$ and 20.56 to $24.66 \%$ in clone 393385.39 and variety Dutch Robyjn for tubers harvested 90 and 120 days after planting, respectively (Table 2). Potato tubers differed in oil content absorbed which ranged from $8.55 \%$ to $14.01 \%$ and $6.4 \%$ to $9.82 \%$ in Dutch Robyjn and Desiree for tubers harvested 90 and 120 days after planting, respectively. Tuber dry matter and oil contents significantly $(\mathrm{P} \leq 0.05)$ differed among the cultivars in either of the harvesting. Tubers harvested 120 days after planting had significantly $(\mathrm{P} \leq 0.05)$ higher

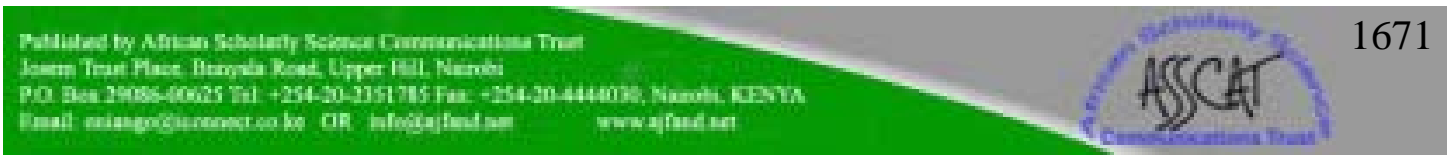


levels of dry matter and oil contents compared to those harvested 90 days after planting.

Tuber dry matter content was found to be negatively correlated to oil contents of deep fried French fries; oil content was higher in tubers of low dry matter content (Figure 1). The loss of moisture was found to be directly related to oil uptake; that is the less moisture lost, the lower the uptake (Figures 2; Table 3).

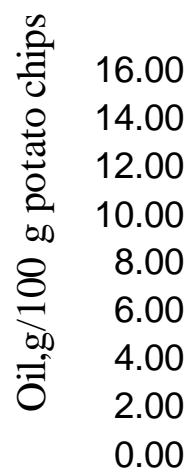

17.00

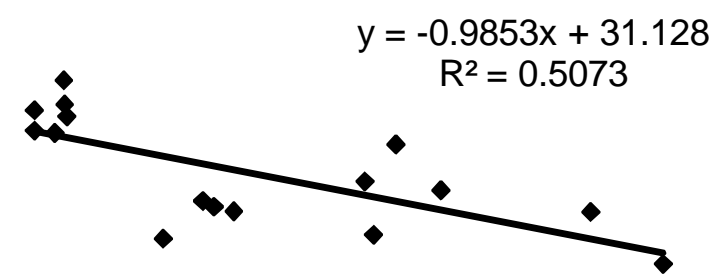

19.00

21.00

23.00

25.00

Dry matter, $\mathrm{g} / 100 \mathrm{~g}$ fresh potato tubers

Figure 1: Correlation of dry matter in raw potato cultivars and oil content of French fries

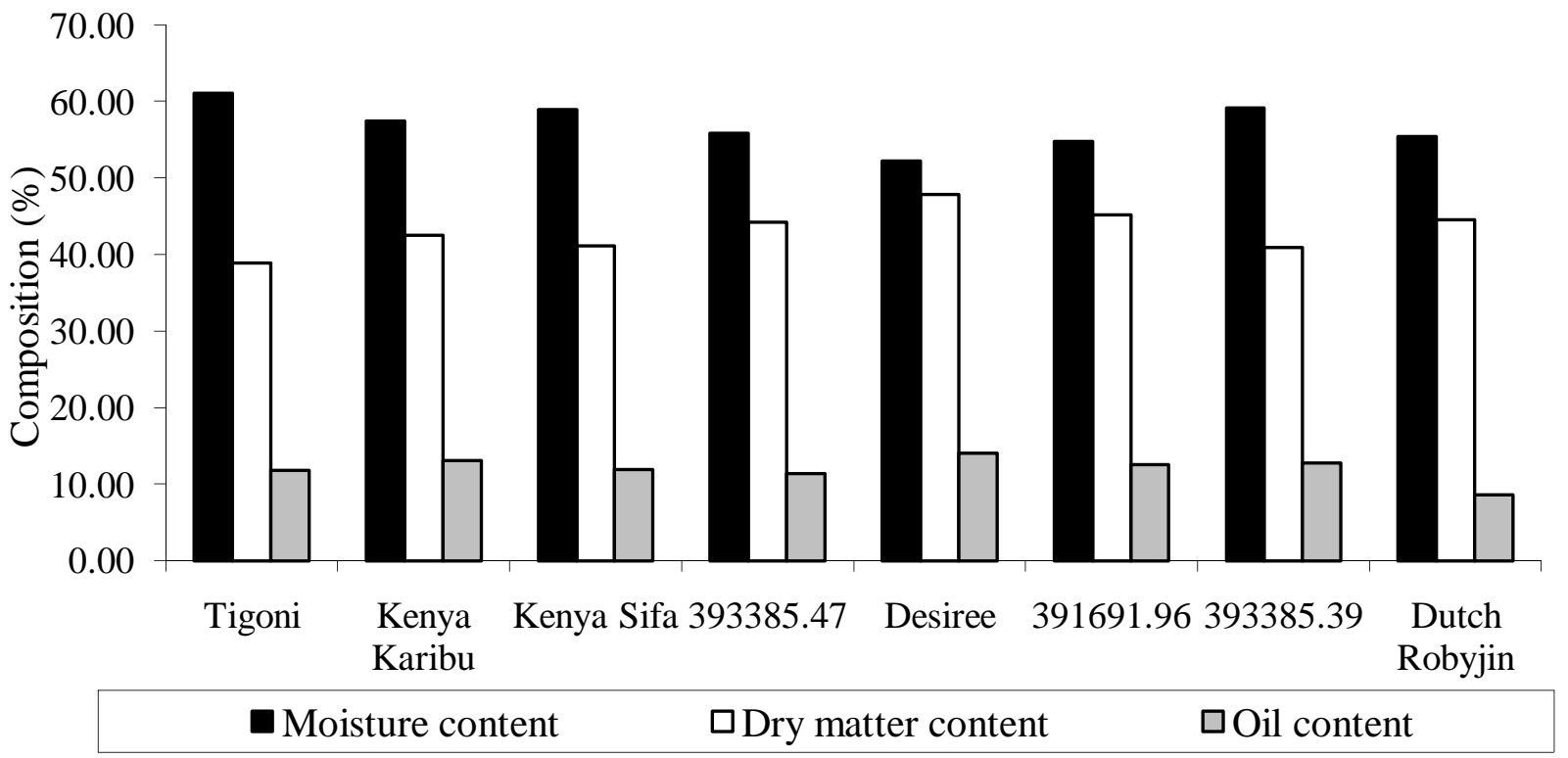

Figure 2: Compositions of French-fries from 8 Kenyan potato cultivars 


\section{Sensory quality characteristics of French fries}

Sensory quality characteristics evaluation using hedonic-scale ratings for colour, texture, flavour, oiliness and overall acceptability of the chips made from 8 cultivars was performed and the data presented in Table 4. No significant $(\mathrm{P} \geq 0.05)$ differences were noted for all the attributes in scores for French fries made from tubers harvested either 90 or 120 days after planting. However, analysis of variance for the sensory attributes for each separate harvest indicated that there were significant $(\mathrm{P} \leq 0.05)$ differences in scores for colour, texture, flavour, oiliness and overall acceptability in French fries made from different cultivars in both harvests. In texture, flavour and overall acceptability, varieties Desiree and Dutch Robyjn had higher scores compared to variety Kenya Sifa and clone 393385.47. Clone 391691.96 had high values almost matching those of Desiree, Dutch Robyjn and Tigoni that scored highly according to the panelists (Table 4). In oiliness, variety Desiree scored poorly, 5.9 and 5.8 compared to Dutch Robyjn that scored 6.4 and 6.46 in tubers harvested 90 and 120 days after harvesting, respectively. Significant correlation $(\mathrm{P} \leq 0.05, \mathrm{r}=-0.512)$ between oil content determined by Soxhlet extraction and sensory scores on oiliness was observed in French fries (Table 5).

\section{DISCUSSION}

The range of dry matter content, 19.50 to $24.07 \%$ and 20.56 to $24.66 \%$ in tubers harvested 90 and 120 days after planting, respectively falls within recommended levels of French fries processing [10]. On the basis of dry matter content, therefore, all the cultivars could evidently be said to be suitable for the production of acceptable French fries. The range is, however, large and could lead to different scores in different sensory attributes in French fries. The stage of maturity had significant effect on the dry matter content of the tubers with those harvested at 120 days after planting (maturity) having higher levels compared to those of early harvesting. This difference could be explained by the fact that tubers harvested after 120 days of planting were well developed structurally and physiologically as opposed to those harvested 90 days after planting [15, 16]. At 120 days, the potatoes are considered generally mature in all aspects. At this point the leaves have become yellow and dry. It is always advisable to harvest potatoes after this period [10].

Significantly more oil was absorbed in tubers harvested 90 days after planting due to lower dry matter content, and underdeveloped cell structures that may have been prone to damage during pre-frying processes such as peeling and cutting. The cellular structure of the potato tubers has been shown to have a bearing on the amount of oil content absorbed during frying [17]. There was a significant correlation between the oil content of chips and dry matter content of potato tubers. The regression line $Y=31.128-0.9853 \mathrm{X}$ was found suitable to estimate final oil content of chips (Y) on the basis of dry matter content $(\mathrm{X})$ in a potato cultivars. In earlier studies of oil uptake by potato crisps, Gravoueille [9] noted that dry matter was a major factor for the potato processing industry, and that it was required to be between $23 \%$ and $25 \%$ to

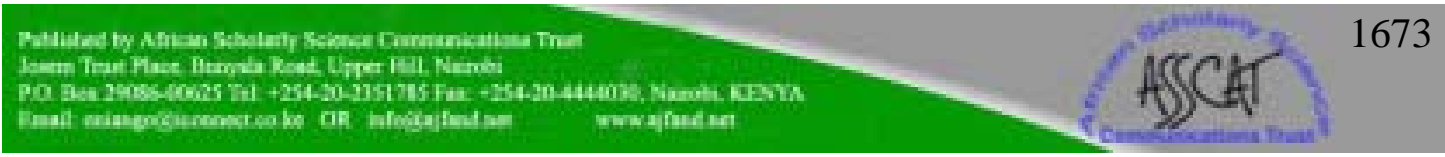


minimize the oil uptake and improve the yield. Potatoes with high dry matter (>20\%) have been shown to produce high yield of French fries with lower oil content than those of lower dry matter [13]. Hagenimana et al. [16] working on sweet potatoes, found a linear relationship between dry matter content and oil uptake in thin sliced crisps, with oil decreasing with increase in the dry matter.

Although the dry matter was relevant and well correlated to oil contents of deep fried French fries, other factors were involved in the oil uptake. Results of this study showed that potato tubers which had similar dry matter contents, had significant differences between the amount of oil in French fries, suggesting other factors were involved in the oil uptake by French fries. Many factors have been reported to affect oil uptake into French fries, including oil quality, frying temperature and duration, product shape, moisture content, solid content, gel strength, and proteins [18]. Ziaiifar et al. [8] agree that oil uptake is a complex phenomenon resulting from interactions between oil and products that undergo numerous physical, chemical, and structural transformations during frying. The different cellular structures may have affected oil uptake by influencing either the loss of moisture or the damage done to the original anatomy during processing $[10,8]$. Apart from inherent genetic make- up, the higher oil content in the variety Desiree may have been due to the greater decrease in moisture content during frying process. The loss of moisture was directly related to oil uptake; that is the less moisture lost, the lower the uptake. This result is in agreement with the work of Gamble et al. [4].

Analysis of variance of the sensory scores indicated that there were significant $(\mathrm{P} \leq 0.05)$ differences in scores of colour, texture, flavour, oiliness and overall acceptability in French fries made from different cultivars in both harvests. This indicates the differences that exist in different potato cultivars even when grown in the same ecological zones with the same treatments. Despite scoring highly in other attributes French fries from variety Desiree had lower sensory scores in oiliness compared to other established varieties from tubers harvested 90 and 120 days respectively. This means that the panelists were able to detect the higher levels of oil as was indicated by Soxhlet extraction method of analysis and this emphasizes the importance of choice of cultivar when preparing French fries [15]. Significant correlation between oil content determined by Soxhlet extraction and sensory scores on oiliness observed in French fries is an indication that the amount of oil absorbed by a cultivar would be detected by the consumer and hence influence the score (higher score for fries of low oil content).

\section{CONCLUSION}

Variety and stage of maturity are two important factors that significantly $(\mathrm{P} \leq 0.05)$ influenced dry matter content in potato tubers which in turn influenced oil content of French fries. These factors were cultivar specific. From the range of oil content of 6.4 $\%$ to $14 \%$ seen in the current study, it follows that consuming a plate of fries (approximately $500 \mathrm{~g}$ ), a person consumes between $32 \mathrm{~g}$ to $70 \mathrm{~g}$ fat depending on the

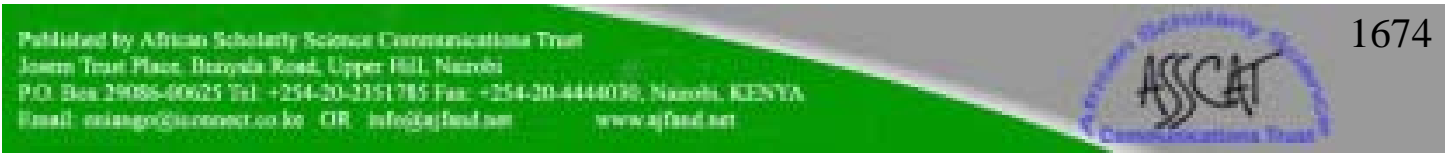




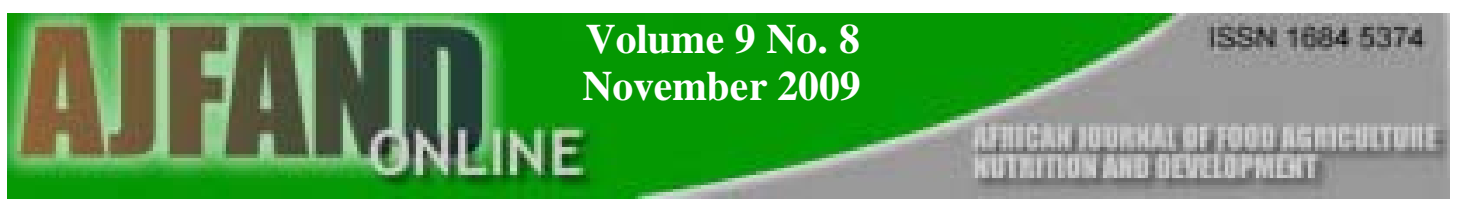

maturity and type of potato cultivar that is used. Selection of appropriate cultivars for processing into French fries is therefore essential. It is beneficial not only to select appropriate cultivars, but also to harvest mature tubers (120 days after planting). However, the influences of temperature and time on the amount of oil absorbed by French fries from these cultivars require further research.

\section{ACKNOWLEDGMENTS}

The authors wish to acknowledge the financial and technical support from the National Potato Research Centre (KARI) and the Food Science and Nutrition Network for Africa (FOSNNA). The roles played by potato breeders; Dr. J. Landeo (CIP), Mr. S. Nderitu, Mr. J. Karinga and Mr. D. Kiplang'at (NPRC) who ensured that the potato materials were available are noted. Appreciation goes to the Food Science Department team at KARI-Tigoni led by Mrs. N. Ngone and Mr. K. Bethuel who offered overwhelming support during the sample preparation and evaluation. Laboratory analysis was accomplished with assistance of Mr. P.N. Karanja, Chief Laboratory Technician at the Jomo Kenyatta University of Agriculture and Technology, and validated at the University of Nairobi with the help of Mr. J. M'Thika and Ms. R. Kamau, food science laboratory technicians. 
Table 1: Description of sensory quality attributes

\begin{tabular}{|c|c|c|c|c|c|}
\hline $\begin{array}{l}\text { Hedonic } \\
\text { scale }\end{array}$ & colour & flavour & texture & oiliness & $\begin{array}{l}\text { Overall } \\
\text { acceptability }\end{array}$ \\
\hline 1 & Dark & $\begin{array}{l}\text { Extremely } \\
\text { poor }\end{array}$ & $\begin{array}{l}\text { Extremely } \\
\text { soft }\end{array}$ & $\begin{array}{l}\text { Extremely } \\
\text { soggy }\end{array}$ & $\begin{array}{l}\text { Extremely } \\
\text { poor }\end{array}$ \\
\hline 2 & Dark/brown & Very poor & Very soft & $\begin{array}{l}\text { Very } \\
\text { soggy }\end{array}$ & Very poor \\
\hline 3 & Brown & Poor & Soft & Soggy & Poor \\
\hline 4 & Yellow/brown & $\begin{array}{l}\text { Below } \\
\text { fair/above } \\
\text { poor }\end{array}$ & $\begin{array}{l}\text { Slightly } \\
\text { soft }\end{array}$ & $\begin{array}{l}\text { Slightly } \\
\text { Soggy }\end{array}$ & $\begin{array}{l}\text { Below } \\
\text { fair/above } \\
\text { poor }\end{array}$ \\
\hline 5 & Yellow & Fair & $\begin{array}{l}\text { Fairly } \\
\text { crispy }\end{array}$ & Fairly dry & Fair \\
\hline 6 & $\begin{array}{l}\text { Slightly } \\
\text { yellow }\end{array}$ & $\begin{array}{l}\text { Below } \\
\text { good/above } \\
\text { fair }\end{array}$ & $\begin{array}{l}\text { Slightly } \\
\text { crispy }\end{array}$ & Dry & $\begin{array}{l}\text { Below } \\
\text { good/above } \\
\text { fair }\end{array}$ \\
\hline 7 & $\begin{array}{l}\text { Golden } \\
\text { yellow }\end{array}$ & Good & crispy & Quite dry & Good \\
\hline 8 & $\begin{array}{l}\text { Very golden } \\
\text { yellow }\end{array}$ & Very good & $\begin{array}{l}\text { Very } \\
\text { crispy }\end{array}$ & Very dry & Very good \\
\hline 9 & $\begin{array}{l}\text { Extremely } \\
\text { golden yellow }\end{array}$ & $\begin{array}{l}\text { Extremely } \\
\text { good }\end{array}$ & $\begin{array}{l}\text { Extremely } \\
\text { crispy }\end{array}$ & $\begin{array}{l}\text { Extremely } \\
\text { dry }\end{array}$ & $\begin{array}{l}\text { Extremely } \\
\text { good }\end{array}$ \\
\hline
\end{tabular}


Table 2: Dry matter content of potato tubers from 8 cultivars and oil contents of their chips

\begin{tabular}{lllll}
\hline & \multicolumn{2}{l}{ Harvested 90 days after planting } & \multicolumn{2}{l}{ Harvested 120 days after planting } \\
\hline Cultivar & Dry matter & oil content & Dry matter & Oil content \\
& content $(\boldsymbol{\%}) \pm \mathbf{s d}$ & $\mathbf{( \% )} \pm \mathbf{s d}$ & content $(\boldsymbol{\%}) \pm \mathbf{s d}$ & $\mathbf{( \% )} \pm \mathbf{s d}$ \\
\hline 393385.39 & $19.50 \pm 0.36$ & $12.77 \pm 0.62$ & $20.56 \pm 0.09$ & $7.44 \pm 0.64$ \\
393385.47 & $22.46 \pm 0.28$ & $11.35 \pm 0.49$ & $22.84 \pm 0.25$ & $9.45 \pm 0.65$ \\
391691.96 & $19.76 \pm 0.40$ & $12.52 \pm 0.78$ & $20.97 \pm 0.42$ & $7.77 \pm 0.33$ \\
Desiree & $19.74 \pm 0.57$ & $14.01 \pm 0.43$ & $22.21 \pm 0.16$ & $9.82 \pm 0.42$ \\
Dutch Robyjn & $24.06 \pm 0.46$ & $8.55 \pm 0.77$ & $24.66 \pm 0.17$ & $6.40 \pm 0.88$ \\
Kenya Karibu & $19.74 \pm 0.25$ & $13.02 \pm 0.73$ & $21.14 \pm 0.23$ & $8.58 \pm 0.11$ \\
Kenya Sifa & $19.50 \pm 0.50$ & $11.92 \pm 0.29$ & $20.88 \pm 0.19$ & $9.01 \pm 0.02$ \\
Tigoni & $19.66 \pm 0.35$ & $11.83 \pm 0.25$ & $22.28 \pm 0.37$ & $7.61 \pm 0.86$ \\
\hline
\end{tabular}

Results are means of three determinations 
Table 3: Moisture content in raw tubers and French fries from 8 Kenyan potato cultivars

\begin{tabular}{|c|c|c|c|}
\hline Cultivar & $\begin{array}{l}\text { Initial moisture content } \\
\text { in tubers }(\%) \pm \mathrm{sd}\end{array}$ & $\begin{array}{l}\text { Moisture content of } \\
\text { French fries }(\%) \pm \mathrm{sd}\end{array}$ & $\begin{array}{l}\text { Loss in moisture } \\
\text { content }(\%) \pm \text { sd }\end{array}$ \\
\hline 391691.96 & $77.56 \pm 0.01$ & $54.80 \pm 0.01$ & $22.73 \pm 0.04$ \\
\hline 393385.39 & $82.04 \pm 0.06$ & $59.05 \pm 0.07$ & $22.92 \pm 0.08$ \\
\hline 393385.47 & $78.56 \pm 0.05$ & $55.53 \pm 0.38$ & $22.80 \pm 0.01$ \\
\hline Desiree & $75.16 \pm 0.14$ & $52.10 \pm 0.14$ & $23.03 \pm 0.04$ \\
\hline Dutch Robyjn & $77.56 \pm 0.09$ & $55.42 \pm 0.02$ & $22.06 \pm 0.01$ \\
\hline Kenya Karibu & $79.35 \pm 0.06$ & $57.40 \pm 0.08$ & $21.73 \pm 0.28$ \\
\hline Kenya Sifa & $78.80 \pm 0.02$ & $58.51 \pm 0.55$ & $19.90 \pm 0.02$ \\
\hline Tigoni & $78.55 \pm 0.02$ & $61.05 \pm 0.06$ & $17.44 \pm 0.05$ \\
\hline
\end{tabular}

Results are means of three determinations 
Table 4: Sensory quality characteristics of French fries (chips) made from 8 Kenyan potato cultivars

\begin{tabular}{|c|c|c|c|c|c|c|}
\hline Cultivar & Harvest & Colour & Texture & Flavour & Oiliness & $\begin{array}{l}\text { Overall } \\
\text { acceptability }\end{array}$ \\
\hline \multirow[t]{2}{*}{ Desiree } & $\mathrm{A}$ & $7.50 \mathrm{a}$ & $6.90 \mathrm{a}$ & $7.00 \mathrm{a}$ & $5.90 \mathrm{~b}$ & $7.40 \mathrm{a}$ \\
\hline & B & $6.77 b$ & $6.60 \mathrm{a}$ & $6.00 \mathrm{~b}$ & $5.80 \mathrm{~b}$ & $6.46 b$ \\
\hline \multirow[t]{2}{*}{ Dutch Robyjn } & A & $7.30 \mathrm{a}$ & $6.80 \mathrm{a}$ & $7.00 \mathrm{a}$ & $6.40 \mathrm{a}$ & $7.50 \mathrm{a}$ \\
\hline & B & $5.92 \mathrm{~cd}$ & $6.53 \mathrm{a}$ & $6.53 \mathrm{ab}$ & $6.46 \mathrm{a}$ & $6.53 b$ \\
\hline \multirow[t]{2}{*}{391691.96} & A & $7.30 \mathrm{a}$ & $6.80 \mathrm{a}$ & $7.10 \mathrm{a}$ & $6.20 \mathrm{ab}$ & $7.45 \mathrm{a}$ \\
\hline & B & $6.53 b$ & $6.57 \mathrm{a}$ & $6.34 \mathrm{ab}$ & $6.65 \mathrm{a}$ & $6.53 b$ \\
\hline \multirow[t]{2}{*}{ Tigoni } & A & $6.90 \mathrm{a}$ & $6.80 \mathrm{a}$ & $6.30 \mathrm{~b}$ & $6.30 \mathrm{a}$ & $6.90 \mathrm{ab}$ \\
\hline & B & $6.69 \mathrm{ab}$ & $6.53 \mathrm{a}$ & $6.53 \mathrm{ab}$ & $6.76 a$ & $6.15 c$ \\
\hline \multirow[t]{2}{*}{ Kenya Karibu } & A & $6.30 \mathrm{~b}$ & $6.00 \mathrm{a}$ & $6.20 \mathrm{~b}$ & $6.10 \mathrm{ab}$ & $6.50 \mathrm{~b}$ \\
\hline & B & $6.31 b c$ & $6.34 \mathrm{a}$ & $6.30 \mathrm{~b}$ & $6.69 a$ & $6.07 \mathrm{c}$ \\
\hline \multirow[t]{2}{*}{393385.39} & A & $6.10 \mathrm{~b}$ & $6.40 \mathrm{a}$ & $6.30 \mathrm{~b}$ & $5.95 b$ & $6.55 b c$ \\
\hline & B & $5.33 \mathrm{e}$ & $5.53 b$ & $5.82 \mathrm{cb}$ & $5.92 b$ & $5.30 \mathrm{~d}$ \\
\hline \multirow[t]{2}{*}{ Kenya Sifa } & A & $5.50 \mathrm{c}$ & $5.60 \mathrm{~b}$ & $6.20 \mathrm{~b}$ & $5.00 \mathrm{c}$ & $6.00 \mathrm{c}$ \\
\hline & B & $6.53 b$ & $6.57 \mathrm{a}$ & $6.34 \mathrm{ab}$ & $6.65 \mathrm{a}$ & $6.53 b$ \\
\hline \multirow[t]{2}{*}{393385.47} & A & $5.30 \mathrm{c}$ & $5.60 \mathrm{~b}$ & $6.30 \mathrm{~b}$ & $5.70 \mathrm{~b}$ & $5.95 \mathrm{bc}$ \\
\hline & B & $5.54 \mathrm{~d}$ & $5.53 b$ & $5.61 \mathrm{c}$ & $5.73 b$ & $5.53 \mathrm{~cd}$ \\
\hline CV (\%) & & 13.45 & 14.00 & 14.08 & 14.43 & 13.63 \\
\hline $\operatorname{LSD}(\mathrm{P} \leq 0.05)$ & & 0.58 & 0.65 & 0.58 & 0.55 & 0.44 \\
\hline
\end{tabular}

Means with the same letter in the same column are not significantly different.

Evaluation was done on 9-point hedonic scale, 5 was the acceptable lower limit.

$\mathrm{A}=$ harvested 90 days after planting, $\mathrm{B}=$ harvested 120 days after planting.

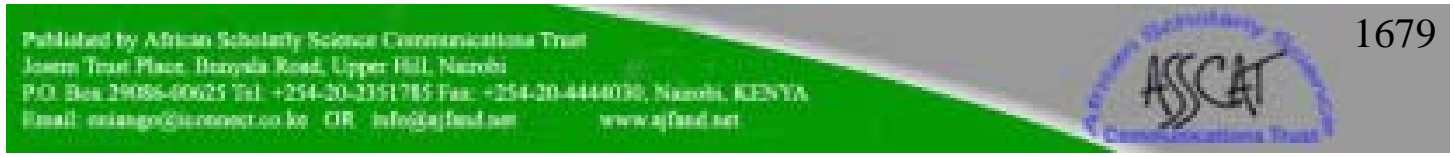


Table 5: Pearson correlation coefficient ( $r$ ) between_oil content determined by Soxhlet extraction and sensory scores on oiliness

\begin{tabular}{lcc}
\hline Parameters & Oiliness & Oil content, g/100g \\
& (sensory scores) & French fries \\
\hline Oiliness (sensory scores) & 1.000 & $-0.512^{\mathrm{a}}$ \\
$\begin{array}{l}\text { Oil content, g/100g French } \\
\text { fries }\end{array}$ & $-0.512^{\mathrm{a}}$ & 1.000 \\
\hline
\end{tabular}

${ }^{\mathrm{a}}$ Significant correlation coefficient $(\mathrm{P} \leq 0.05),(\mathrm{N}=32)$ 


\section{REFERENCES}

1. Durr $\mathbf{G}$ and $\mathbf{G}$ Lorenzl Potato production and utilization in Kenya. International Potato Center (CIP), Nairobi, Kenya. 1980.

2. GOK. Ministry of Agriculture Potato standards In: The crop production and livestock act. Kenya Gazette supplements no.38, Nairobi. 2005.

3. Walingo A, Lung'aho C, N'gang'a N, Kinyae PM and JN Kabira Potato marketing, storage, processing and utilization in Kenya. Proceedings of $6^{\text {th }}$ Triennial congress of the African Potato Association, Agadir, Morocco. 2004.

4. Gamble MH, Rice $\mathbf{P}$ and JD Selman Relationship between oil uptake and moisture loss during frying of potato slices. J. Food Sci. 1987; 22: 233-241.

5. Aguilera JM and $\mathbf{H}$ Gloria-Hernandez Oil absorption during frying of frozen par-fried potatoes. J. Food Sci. 2000; 65: 477-479.

6. Hagenimana V, Karuri EG and MA Oyunga Oil content in fried processed sweet potato products. J. Food Proc. Pres. 1998; 22: 123-137.

7. O'Connor CJ, Fisk KJ, Smith BG and LD Melton Fat absorption in French fries as affected by different potato varieties and processing. J. Food Sci. 2001; 66: 903-908.

8. Ziaiifar MA, Achir N, Courtois F, Trezzani I and G Trystram Review of mechanisms, conditions, and factors involved in the oil uptake phenomenon during the deep-fat frying process. Int. J. Food Sci. Technol. 2008; 43: 14101423.

9. Gravoueille $\mathbf{J} \mathbf{M}$ Utilisation de la pomme de terre pour l'alimentation humaine. In La pomme deterre. Production, Amelioration, Ennemis et Maladies, Utilisations, (P. Rousselle, Y. Robert, and J.C. Crosnier, eds.). INRA, Paris, France. 1996: 452-498.

10. Kabira JN and B Lemaga Quality evaluation procedures for research and food industries applicable in East and Central Africa. Kenya Agricultural Research Institute Publication, Nairobi, Kenya. 2006.

11. Lung'hao $\mathbf{C}$ and JN Kabira A guide to growing table potatoes. Kenya Agricultural Research Publication, Nairobi, Kenya. 1999.

12. AOAC. Official methods of analysis, $14^{\text {th }}$ ed., Ass. Off. Anal. Chem., Washington, DC, USA. 1984.

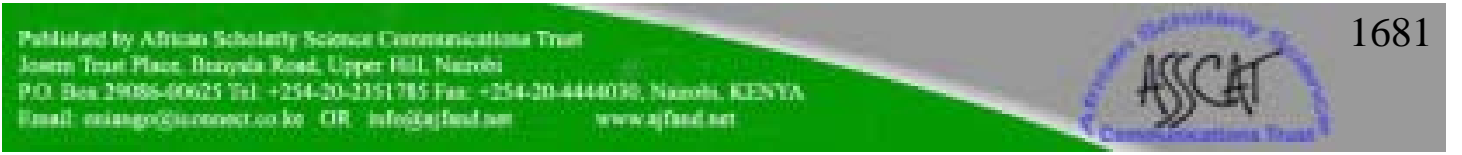


13. Lulai E and PH Orr The influence of specific gravity on oil content of chips. Am. Potato J. 1979; 56: 379-390.

14. Larmond E Methods for sensory evaluation of food. Food Research Institute, Central Experiment Farm, Canada Dept. of Agriculture, Ottawa. 1977.

15. Burton WG The potato. $3^{\text {rd }}$ ed. Longman Group UK Ltd, England. 1989: 286360.

16. Hagenimana V, Hall $\mathbf{A}$ and $\mathbf{J}$ Low Sweet potato processed products in Kampala. NRI and CIP, Kampala, Uganda. 1996.

17. Lloyd BJ, Farkas BE and KM Keener Quality comparison of French fry style potatoes produced by oven heating, immersion frying and controlled dynamic radiant heating. J. Food Proc. Pres. 2004; 28: 460-472.

18. Pinthus EJ, Weinberg $\mathbf{P}$ and $\mathbf{S}$ Saguy Criterion for oil uptake in deep fat frying. J. Food Sci. 1995; 58: 204-205. 